\title{
Editorial
}

\section{Marketing challenges in the next decade}

Journal of Brand Management (2010) 17, 315-316. doi:10.1057/bm.2010.2

Marketing is faced with some daunting challenges in the next decade. Change is everywhere. New categories are emerging and receding at a rapid rate. Communication is increasingly fragmented and under the control of the audience rather than the brand. The fast moving digital world adds new options and complexity. It is harder than ever for an offering or a marketing program to break out. Let me discuss six of these challenges.

Getting a seat at the table. Marketing needs to get a firmer hold on a seat at the executive table where the real action is. It can and should be a primary driver of business strategy - specifying the value proposition, the selection of the product-markets in which to invest, and the development of assets and competences, especially those around branding that will protect a business from competition. Because marketing brings customer and market insight to the table, it is important to develop and refine the ability to create and evaluate those insights and turn them into actionable programs. Unless the strategy is right and clearly defined, tactical programs and investments are unlikely to be effective however creative they might be.

Living in a global world. It is a global world and new information sources, branding expertise, organizational forms are needed. The key arenas will be China, India, and perhaps Brazil and Russia. It is clear that applying products and brands that work in the West is not a reliable recipe for success. It is also clear that having country brand specialists go it alone is not wise. There need to be ways to apply and adapt the brand experience and expertise of central marketing. The product and brand needs to be tailored to the country and region involved, but there need to be ways to capture the scale and successes of the brand elsewhere.

Spanning silos. The Chief Marketing Officer (CMO) team needs to address what I called the silo crisis in my last book, Spanning Silos. ${ }^{1}$ Product, country and functional silos have paralyzed organizations, inhibited cross silo offerings and brand building programs, which has resulted in dramatic resource misallocation, created internal and external brand confusion, and prevented firms from reaching the elusive integrated communications goal. The solution is to develop programs and policies that will lead to cooperation and communication replacing competition and isolation. Some centralization will be needed, but a lot of progress can be made with aggressive use of teams, effective information systems, and the ability to recognize excellence wherever it occurs, and to find ways to leverage it beyond the silo in which it appeared.

Energizing brands. Brands more than ever need energy. In the book The Brand Bubble, 
the authors note that brand equities have been declining across the board except for those brands that have energy. ${ }^{2}$ Yet energy is not easy to come by, even for (or maybe especially for) large established brands even those with market share leadership. One route to energy is what I call branded energizers. ${ }^{3}$ When the offering itself is not exciting, or if it is between breakthrough innovations, it can find something with energy, such as branded social programs or proprietary sponsorships, that can be attached to the brand. Another approach is to deploy programs that involve the customer or potential customer. We always seem to have to relearn the lesson that customer involvement works.

Defining a new category or subcategory. Perhaps the biggest opportunity is to create a point of differentiation that defines a new category or subcategories. It is hard to find a point of differentiation that is valued by the market and not quickly copied. But it is possible as the experience of iPod, iPhone, Prius, Best Buy, Whole Foods, H\&M and a host of others have shown. It doesn't only take customer insight and an organizational ability to execute on that insight, but an ability to build barriers around customer relationships and to generate ongoing innovation to prevent others from enjoying the benefits of the new offering.

Being a player in world's social issues. Marketing also needs to consider its role in the broader picture of being a player in the world com- munity. There is a role going forward for marketing to participate in some key issues. Should brands consider a link to programs that benefit society? What is the role of sustainability in marketing and brand building? Does marketing have any role in combating obesity and other unhealthy consumer trends? Can marketing aid organizations attempting to solve the problems of global warming, the use of alternative energy, hunger, water, disease and so on? How? Does marketing have any responsibility to address the perceptions and reality that business offerings and marketing programs sometimes encourage wasteful consumption? The fact is that customers are increasingly rewarding firms that visibly get involved in social issues, and which provide practical incentives to move marketing to the larger stage.

The above is only a partial list. But it does reflect some opportunities as well as challenges as we move marketing into the next decade and beyond.

\section{REFERENCES AND NOTE}

(1) Aaker, D. (2008) Spanning Silos: The New CMO Imperative. Boston, MA: Harvard University Press.

(2) Gerzema, J. and Lebar, E. (2008) The Brand Bubble. San Francisco, CA: Jossey-Bass.

(3) More details on the brand energizer concept can be found in Aaker, D. (2004) Brand Portfolio Strategy. New York: The Free Press, pp. 144-153.

David Aaker

Editorial Board

E-mail: daaker@prophet.com 